\title{
CORPORATE DIGITAL RESPONSIBILITY: FOUNDATIONS AND CONSIDERATIONS FOR ITS DEVELOPMENT ${ }^{1}$
}

\author{
JOSÉ LONDOÑO-CARDOZO \\ (iD) https://orcid.org/0000-0002-5739-1191 \\ MARÍA PÉREZ DE PAZ ${ }^{1}$ \\ (D) https://orcid.org/0000-0002-6704-0272
}

To cite this paper: Londoño-Cardozo, J., \& Pérez de Paz, M. (2021). Corporate digital responsibility: Foundations and considerations for its development. Revista de Administração Mackenzie, 22 (6), 1-31. doi:10.1590/1678-6971/eRAMD210088

Submission: Mar. 21, 2021. Acceptance: Sep. 13, 2021.

1 Special thanks to María José Barrios Bonilla for her selfless work in translating this document into the Portuguese language.

2 Universidad Nacional de Colombia (Unal), Cali, Colombia.

\section{(cc) BY




\section{ABSTRACT}

Purpose: To propose corporate digital responsibility as a new area of interest for social accountability in the contexts of technologies that are part of the 4.0 industries.

Originality/value: In this regard, it was found that there is not enough theoretical and legal foundation that allows different types of organizations to face the implications of the adoption of new technologies. Therefore, essential foundations and considerations are raised for the development of corporate digital responsibility.

Design/methodology/approach: The document presents a hermeneutical investigation based on a systemic literature review within the framework of two investigations. The first addressed the relevance of creating a new subject for traditional social responsibility in digital contexts, and the second demonstrated the epistemological need for social responsibility in technologies.

Findings: Firstly, the fact that new technologies pose a social risk makes them a subject of social responsibility study. Secondly, the absence of regulations on industry 4.0 and the unpredictability of the advancement of technologies is not a limitation for creating a scenario of corporate digital responsibility. To conclude, the development of social responsibility in digital contexts is possible and necessary. However, we must be attentive to the variables of social risk that may arise with each new technology. Therefore, a constant review of the foundations and bases of corporate digital responsibility is needed.

\section{KEYWORDS}

Social risk. Corporate social responsibility. Industries 4.0. Digital transformation. Artificial intelligence. 


\section{INTRODUCTION}

The adoption of technologies in all social contexts brings new opportunities, ways of working, communication mechanisms and transforms how some daily activities are carried out. Technology has become a factor that must be considered by both individuals and organizations, private and state. However, it can also have the opposite effect. For example, job insecurity and unemployment, communication problems, or excess of social interaction.

This duality of technology in different social contexts encourages debates about its use, relevance, and the relationship between it and man in society. In the case of organizations, one of the phenomena with the greatest impact is the appearance of artificial types of intelligence that manipulate and transmit users' information. There is a marked debate about the displacement of the labor force; the generation, storage, and transmission of data; and the implications that all this entails.

Some authors propose as a solution the implementation of ethical guidelines and social responsibility policies as a mechanism to reduce the externalities of technological implementation, especially those related to industries 4.0 (Lobschat et al., 2019; Londoño-Cardozo, 2020). In general, there are two positions regarding the implementation of social responsibility policies or the creation of an ethical framework for digital contexts. The first is about creating a Digital Social Responsibility parallel to traditional social responsibility. The second proposes that digital contexts be understood as a new subject or scope for traditional social responsibility. Currently, there is no consensus on what should be the best way to address corporate social responsibility (CSR) concerning technology. The lack of consensus is a problem since technology is at the mercy of individual values that do not necessarily seek social sustainability.

For all the above, this document provides theoretical and legal arguments that identify the relevance of the second position of application of social responsibility in digital contexts over the first one. This does not ignore that recognizing the digital as a new application of social responsibility poses some challenges that must be overcome; among them, the proper use of new devices in organizations and their responsibility for action.

The document is ordered as follows. In the first place, methodological support is presented. This was, especially, a systemic literature review focused on a hermeneutical analysis of information sources. Second, the fundamentals of traditional CSR are presented. Its principles and subjects of 
application are addressed in this section. The implementation of what TelloCastrillón called fundamental CSR (2018b) is defended. Third, industry 4.0 appears and the need for its regulation through social responsibility policies is highlighted. This section begins with a description of technological evolution based on the works of del Val Román (2016a, 2016b), Maisiri et al. (2019), Melnyk et al. (2019), Vaidya et al. (2018), and Xu et al. (2018). Then, the technologies that are part of Industries 4.0 are listed. To finish this section, based on the work of Kemisch (20211) and Kasperson et al. (1988), the epistemological need for social interest for digital is justified.

Fourth, corporate digital responsibility (CDR) is proposed as a new subject or context of interest for CSR. In this section, some epistemological and ontological considerations for its implementation are presented. The approach to technologies of the industry 4.0 is analyzed, the new groups interested in digital are listed, and some application cases are shown. Finally, some conclusions are raised.

\section{METHODOLOGY}

This document reports qualitative research results, given that this type of research is used, to a greater extent, to "understand a social situation as a whole, taking into account its properties and dynamics" (Bernal Torres, 2010, p. 60). Additionally, qualitative research "is capable of handling paradoxes, uncertainties, ethical dilemmas and ambiguities" (Hernández Sampieri, Fernández Collado, \& Baptista Lucio, 2014, p. 10) and focuses on an interpretive perspective of the actions of human beings and of the institutions that they create.

To fulfill its function, one of the main tools of this type of research is hermeneutics, since "in the research process questions are usually produced before, during or after data collection and analysis" (Hernández Sampieri \& Mendoza Torres, 2018, p. 8). In this sense, this document is the result of a hermeneutical analysis of documentary sources to discuss the results of this process.

In general, a systemic literature review was used based on what was stated by Chicaíza-Becerra, Riaño Casallas, Rojas-Berrio, and Garzón Santos (2017). In this sense, the review had three stages: 1. Exploratory, 2. an indepth search in the selected databases, and 3. the analysis and discussion of the information. 


\subsection{Information sources}

All the sources consulted were secondary. In essence, scientific articles, books and book chapters of research results, scientific or technical reports, graduate theses, and working documents available in academic and governmental databases were reviewed. The guidelines of García Molina \& Chicaíza Becerra (2011) were followed regarding the recommended documents for systemic literature reviews, from now on referred to as systemic literature reviews (SLR), in economic and social sciences.

\subsection{Stages of systemic literature review}

The first stage of the systemic review consisted of exploration. Here, a first review was made in the databases to identify search criteria for information in different languages. Based on these criteria, the in-depth search was continued.

At this stage, a search was carried out for sources in databases such as Scopus, ScienceDirect, Latindex, Econlib, and institutional repositories from different universities. In general, the search equation comprised the keywords listed in Figure 2.2.1.

(Figure 2.2.1)

INFORMATION SEARCH CRITERIA

\begin{tabular}{l}
\multicolumn{1}{c}{ Keyword } \\
\hline Trabajo contingente \\
Digitalización \\
Transformación digital \\
Plataformas digitales \\
Protección de datos \\
Contingent work \\
Shadow workforce \\
Platform economy \\
Digital platforms \\
Responsabilidad social digital \\
Digital corporate responsibility \\
Ética de la tecnologia \\
Moral en la tecnologia \\
Inteligencia artificial
\end{tabular}


Based on these criteria, different documents were found that were synthesized in reading matrices and grouped by categories as part of the third phase of the SLR. The documents that defined or exposed a need to implement social responsibility criteria in technology were grouped into the same category, those that laid the basis for discussion in another one, and the related theoretical documents such as technology, moral and ethical issues in the third one. In general, little theoretical approach was found about the relationship between technology and social responsibility.

\section{TRADITIONAL CORPORATE SOCIAL RESPONSIBILITY}

Traditional CSR has an interest in different matters or aspects of society and organizations. These approaches, in general, are transversal to all the activity of these social entities and, therefore, it becomes an inalienable component of their strategies. In this sense, this section will make a brief presentation of the fundamentals of traditional CSR.

\subsection{Fundamentals of corporate social responsibility}

Some authors consider that social responsibility is directed towards creating value for the organizations' shareholders (Friedman, 1970). Despite this, the theoretical development went beyond this position and reached the relationship between social responsibility and sustainable development (Tello-Castrillón, 2018b; Tello-Castrillón \& Londoño-Cardozo, 2020; TelloCastrillón \& Rodríguez Córdoba, 2014).

To reach such relationship, it was considered that social responsibility is limited to morality immersed in organizational ethics (Aßländer, 2011; Enderle, 2010; Ungericht \& Hirt, 2010) and, therefore, must seek a balance between the organizational needs and the social ones. The path to this goal is creating a code of conduct or what is known as sustainability policies (Perrone, Engelman, \& Reppold, 2014). The foregoing consolidates traditional CSR as a transversal activity to all organizational action (Jenkins, 2009; Tello-Castrillón, 2021b; Tello-Castrillón \& Londoño-Cardozo, 2020; Tello-Castrillón \& Rodríguez Córdoba, 2014), of voluntary origin (Jenkins, 2009; Tello-Castrillón \& Rodríguez Córdoba, 2014, 2016) and in harmony with stakeholders (Lozano Correa, 2017; Olivero Arias, Morales Vergara, \& Alvarado Márquez, 2017; Tello-Castrillón \& Londoño-Cardozo, 2020; TelloCastrillón \& Rodríguez Córdoba, 2014; Volpentesta, 2015, 2017). Based on 
this theoretical support, Tello-Castrillón proposed two ways to understand traditional CSR (see Figure 3.1.1).

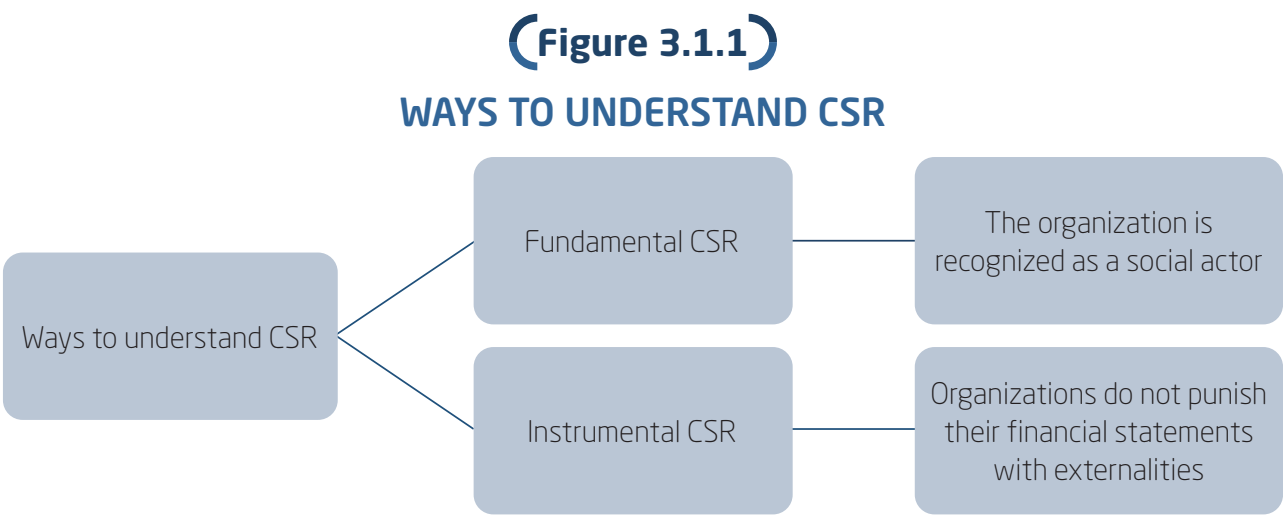

Source: Elaborated by the authors based on Tello-Castrillón (2018b, 2021a, 2021b).

Generally, organizations that decide to apply instrumental CSR policies take advantage of government figures that allow them to lower the taxes imposed on them or to access to public subsidies, among others (TelloCastrillón, 2018b, 2021a). In contrast, organizations that decide to apply CSR to all of their business and charge these costs in their financial statements practice fundamental CSR. This is the way it should be considered in all organizations.

CSR policies must take into account the principles initially raised from the International Organization for Standardization (ISO) in a transversal way, that is, fundamental CSR. Likewise, its field of action is focused on the subjects or application scenarios of CSR in organizations (Tello-Castrillón \& Londoño-Cardozo, 2020) (see Figure 3.1.2). In general, these are closely related to the functional areas of the organization.

Top management plays a leading role in the promulgation of CSR policies and general actions of the organization. This grounds that governance, or corporate governance, is considered as one of the main subjects of study of CSR (de Fréminville, 2020; Sosa Cardona, Tello-Castrillón, \& Pineda Henao, 2020; Tello-Castrillón, 2014, 2021a, 2021b; Tello-Castrillón, Rodríguez Córdoba, \& Varela Barrios, 2013). The key for an organization to assume socially responsible attitudes is in corporate governance with ethical, fair, and inclusive guidelines (Fréminville, 2020; Elkington, 1998, 2004). 


\section{(Figure 3.1.2) \\ SUBJECTS OF INTEREST OF THE TRADITIONAL CSR}

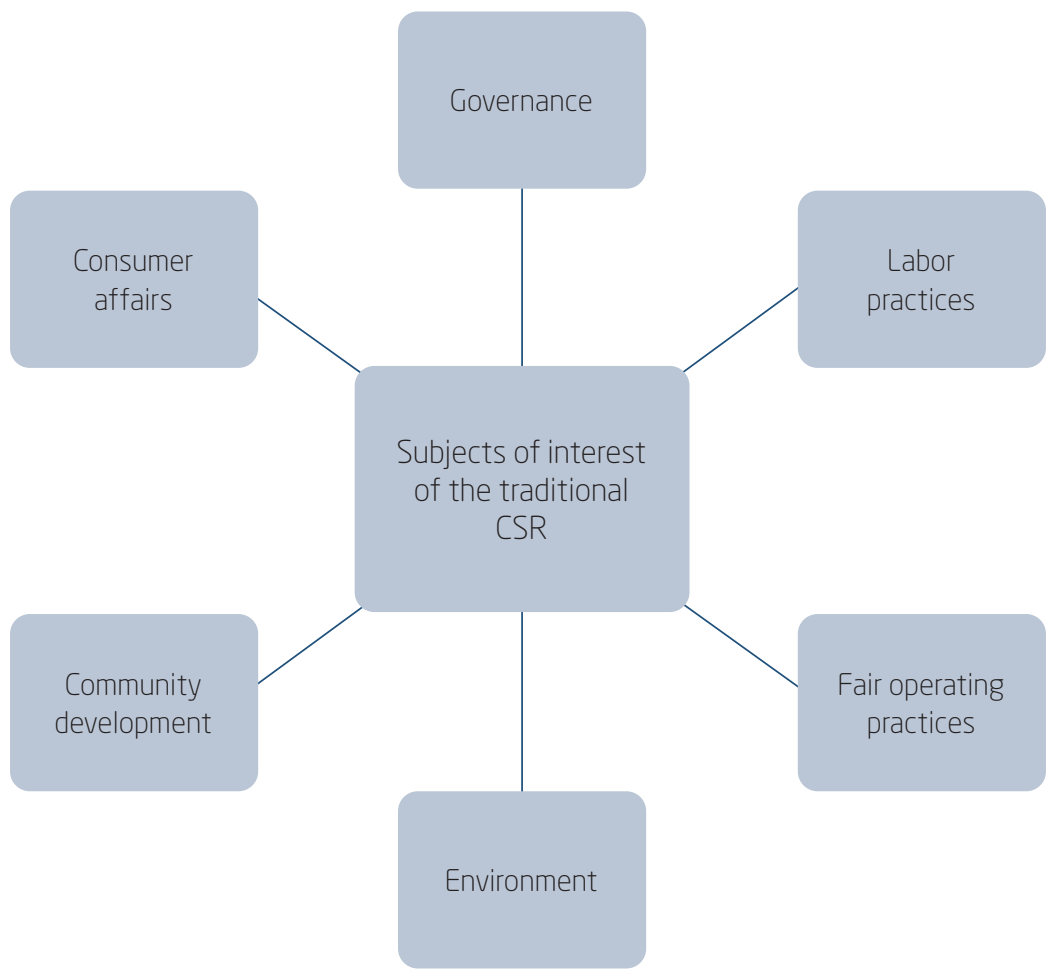

Source: Elaborated by the authors based on Tello-Castrillón \& Londoño-Cardozo (2020).

Another interest is the organization's internal and external work practices. In general, this is one of the aspects that organizations least take into account when formulating their CSR policies, since they consider that meeting the minimum requirements of the law has CSR. Concatenated to this, the following subject appears: fair operating practices with a special relationship with labor practices and stakeholders (Tello-Castrillón \& Londoño-Cardozo, 2020; The Global Compact, 2000).

Regarding the environment, the actions of the organizations should be directed towards the compensation of the environmental impact of their operations and towards its mitigation. This matter is totally related to the sustainability of the planet (Tello-Castrillón \& Londoño-Cardozo, 2020). Similarly, the environment is related to the development of the community. Here, emphasis should be placed on the retribution and care of the organization's community (Tello-Castrillón \& Londoño-Cardozo, 2020). For this 
purpose, people's culture and sociocultural characteristics must be identified and respected with the intention of minimizing intervention in social identity (Elkington, 1998, 2004).

From the hand of the community and the environment, there is an interest in consumer affairs from which sustainable marketing strategies are promoted, the promotion of reusable goods or without programmed obsolescence (ISO, 2010; Tello-Castrillón \& Londoño-Cardozo, 2020).

\section{INDUSTRY $\mathbf{4 . 0}$}

In order to understand the functioning of contemporary technology, it is necessary to review the different industrial revolutions and technological cycles (see 4.1). In general, digitization is considered to be the most obvious manifestation of the Fourth Industrial Revolution.

The digital age is known colloquially as industry 4.0 (Maisiri, Darwish, \& Dyk, 2019; Vaidya, Ambad, \& Bhosle, 2018; Xu, David, \& Kim, 2018). However, some authors call this same technological phenomenon as industry 5.0 (Melnyk et al., 2019; Skobelev \& Borovik, 2017). The difference between both concepts is the evolution from the emergence and development of technology and the beginning of its use, industry 4.0 (Al Faruqi, 2019; Skobelev \& Borovik, 2017), until its full adoption by society, industry 5.0 or digital society (Al Faruqi, 2019; Özdemir \& Hekim, 2018; Skobelev \& Borovik, 2017). Despite this, this document does not intend to deepen into this debate, since the fundamentals that are discussed are valid in both industry 4.0 and 5.0. Therefore, industry 4.0 will be used, given its greater acceptance today.

Industry 4.0 is characterized by being mainly composed of a group of technologies. These are: 1 . cloud services, 2 . mobility, 3. advanced and collaborative robotics, 4. 3D printing, 5 . social platforms, 6 . big data, and 7 . machine to machine (Val Román, 2016a, 2016b). In general, these technologies can be considered cyber-physical systems, since they provide objects or physical components with computing capabilities and, in many cases, with artificial intelligence (AI), hereinafter AI (Sanz Pereda, 2018).

The man-machine relationship is closer with each of the technological revolutions (Pérez de Paz, 2016). The new creations interfere in matters of interest of the CSR either as transmitters of information, in the case of big data, or as agents, in the case of advanced robotics. 


\section{(Figure 4.1) \\ INDUSTRIAL REVOLUTIONS AND THEIR CHARACTERISTICS}

Industrial revolutions

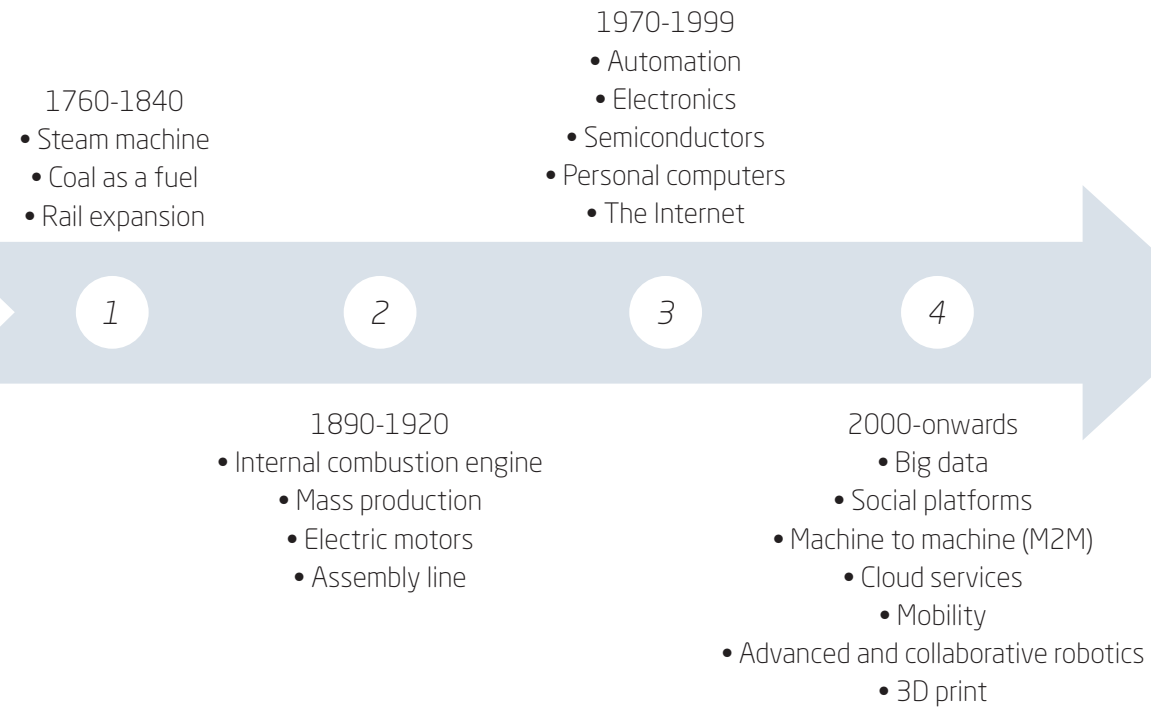

Source: Elaborated by the authors based on Val Román (2016a, 2016b), Maisiri et al. (2019), Melnyk et al. (2019), Vaidya et al. (2018), and Xu et al. (2018).

\subsection{The need for CSR in digitization}

Kermisch (2011) and Kasperson et al. (1988) considered that there are two types of risks: classic and social. The classic risks are quantifiable damages; the hazard prevention procedure is based on scientific and technical procedures. They are usually found in disaster prevention cases where nature is the cause of the hazards. For Kasperson et al. (1988), social risks are those in which psychological, social, institutional, and cultural processes can amplify or attenuate the perception of the level of disaster (1988). These appear with technological innovations, such is the case with AI.

The social as a new sphere of risk offers two implications: 1. the risk as a characteristic of technical society and 2. the demand for social responsibility for its technological creations. Ulrich Beck (2002) and Giddens (1998) called today's society a risk society: "the idea of modern risk only manifest itself in future-oriented societies animated by a desire for control, more particularly that of controlling a future conceived as a territory to be colonized" (Kermisch, 2011, p. 22). This is, in fact, the state of today's society, always 
looking for and creating new devices that guarantee the desired future. For example, it is currently common for each person to carry a smartphone with them or to have a laptop or a tablet (Molina García, 2011; Navarro Güere, 2011). These devices facilitate people's work and allow connectivity to the internet from almost anywhere in the world. Their versatility facilitates communication, work, and leisure for people and makes them inherent tools in the work of organizations. Mobile devices are the main instrument for generating and consulting information. They connect to the cloud, facilitate the emergence of social platforms and serve as geolocation tools. This technology facilitates direct communication between one machine and another, without human intervention, or Machine to Machine (M2M) (Weyrich, Schmidt, \& Ebert, 2014).

Now, more than ever, the risk is developed in industry 4.0 and 5.0 technologies. As Rohrmann \& Renn (2000, p. 14) pointed out: "Risk can be understood as the possibility that human actions, situations or events may occur. They lead to consequences that affect what people value". An organization in constant technological innovation to conquer the future cannot lose sight of the values that form the basis of the future that it wants to build. Otherwise, the social horizon of the organizations is lost. Therefore, the cost-benefit problem in technology goes beyond the episteme and becomes a social problem (Pérez de Paz, 2020). That is, when technologies are seen as a threat to society's values such as freedom, security, peace, common interest, respect, it goes from the epistemological to the social level. Thus, technologies 4.0 and 5.0 are a matter of epistemology and society.

Therefore, it can be said that, if a way is found to protect these values, the social part that involves technological risk would be covered. This is where social responsibility comes in, and its misión is to protect social values from technological risks. Risk is a concept that buries men's awareness of their own actions. Therefore, men must act to avoid catastrophes beyond the calculation of probability and not leave everything in the hands of the selfregulation of science and technology.

\section{THE NEW SUBJECT OF CORPORATE SOCIAL RESPONSIBILITY}

[CSR] is the set of shared values and norms guiding an organization's operations concerning digital technology and data creation and operation. It requires tech companies, individual developers and designers, 
and any corporate actor employing digital technologies or data processing to be aware that the code they produce or deploy and the data they collect and process inherently create an ethical responsibility for them (Lobschat et al., 2019, p. 3).

There is no precedent for the power that digitization, data analysis, algorithms, and artificial intelligence bring to data managers, organizations, and people. This creates ethical problems that must be solved as quickly and independently as possible. By applying the arguments of Rincón Orozco (2020) in this discussion, questions can be raised, such as:

- What is morally correct with data and digital information?

- How should information managers act in organizations?

Next, the existence of legal antecedents that allow building a social responsibility focused on digital will be reviewed.

In science fiction, there are several proposed laws of AI. Among them, the most famous are the laws of robotics by Asimov (2017). However, these laws are neither legislative nor regulatory of AI, as they do not belong to any current legislation. According to the United Nations Interregional Crime and Justice Research Institute - Unicri (2020) AI strategic document schedule, planning for AI legislation and regulation begins in 2016 (Figure 5.1).

\section{(Figure 5.1)}

\section{TIMELINE OF THE YEAR IN WHICH COUNTRIES BEGAN} TO TAKE AI CONSIDERATIONS

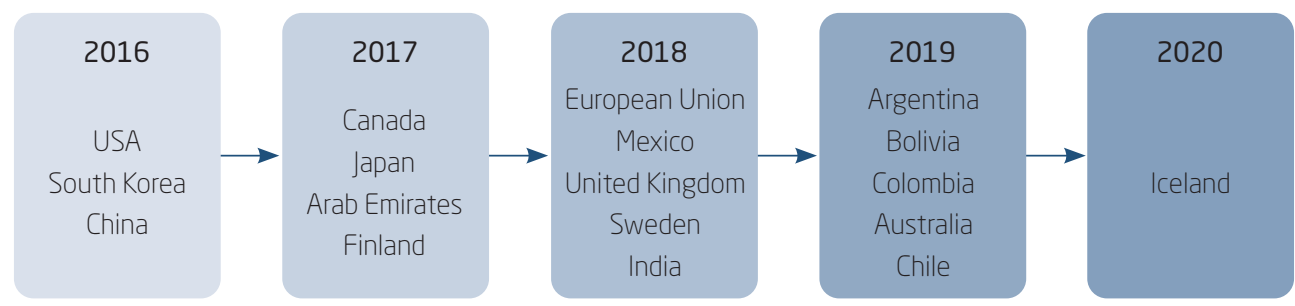

Source: Elaborated by the authors based on Unicri (2020)

Figure 5.1 shows the existence of an interest in legislating on AI. However, the current state of the laws can be found in the Worldwide AI Laws and Regulations (Cognilytica, 2020) (see Figure 5.2). Regarding this report, emphasis will be placed on two sections: 1 . AI ethics and bias and 
2. malicious AI. The first section portrays ethics and politics in the field of AI; the second section allows to contextualize AI in a scenario of danger for organizations. The AI ethics and bias section results show a world not very interested in the regulation of artificial intelligence. Only $4 \%$ of the countries or regions discuss this issue. As for the malicious AI section, the outlook is even less encouraging. No country or region regulates or discusses the possible appearance of an AI that can be used maliciously in organizations. These data can be confirmed with the current state of the debate on the subject in the Organisation for Economic Co-operation and Development (OECD) and the European Parliament.

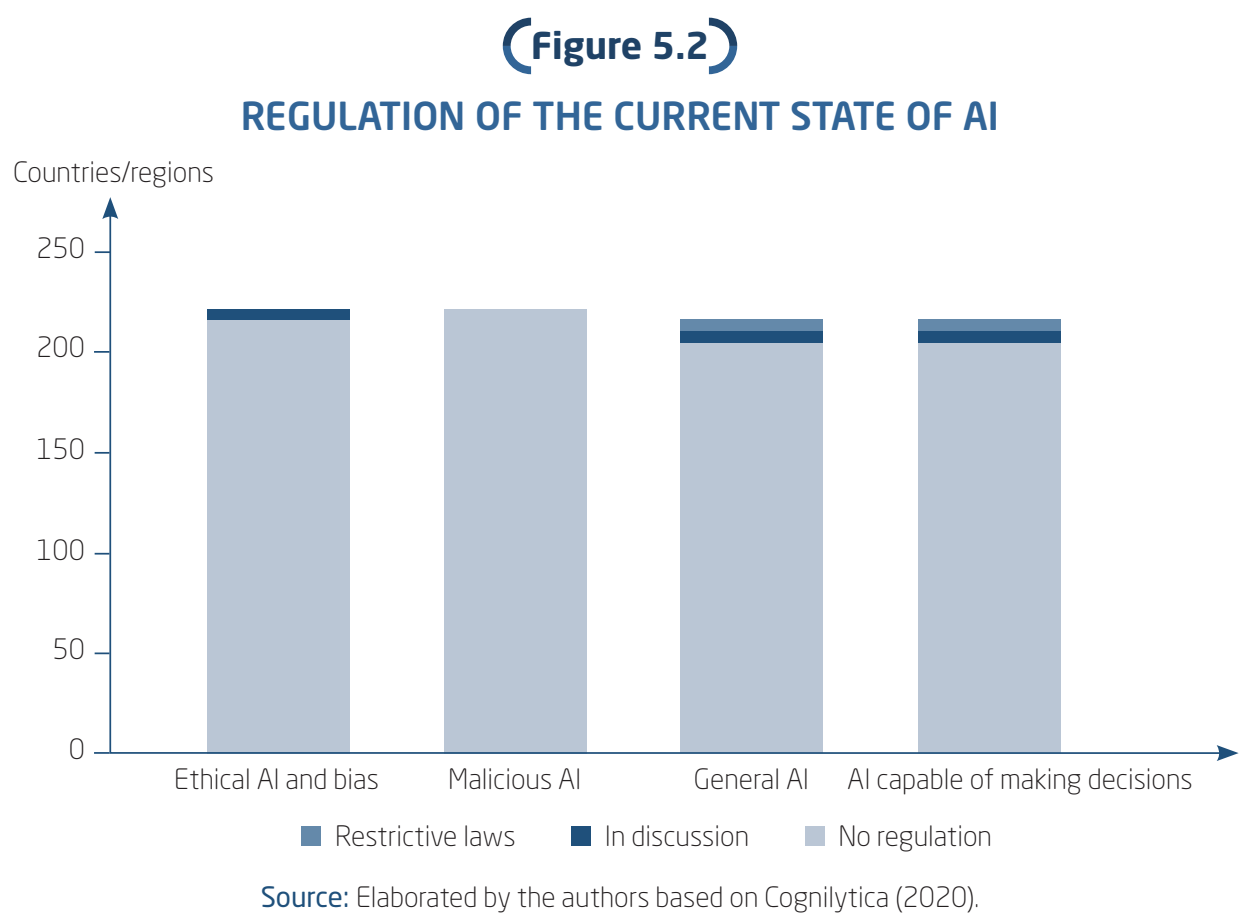

On May 22, 2019, 42 countries adopted the OECD Intergovernmental Guiding Principles on artificial intelligence, including the top three AI patent producers: Japan, United Kingdom, and United States (OECD, 2021). The proposed guidelines include five principles for the responsible deployment of reliable AI and five recommendations for public policies and international cooperation (figures 5.3 and 5.4). 


\section{(Figure 5.3)}

\section{FIVE VALUE-BASED PRINCIPLES FOR RESPONSIBLE DEPLOYMENT OF RELIABLE AI}

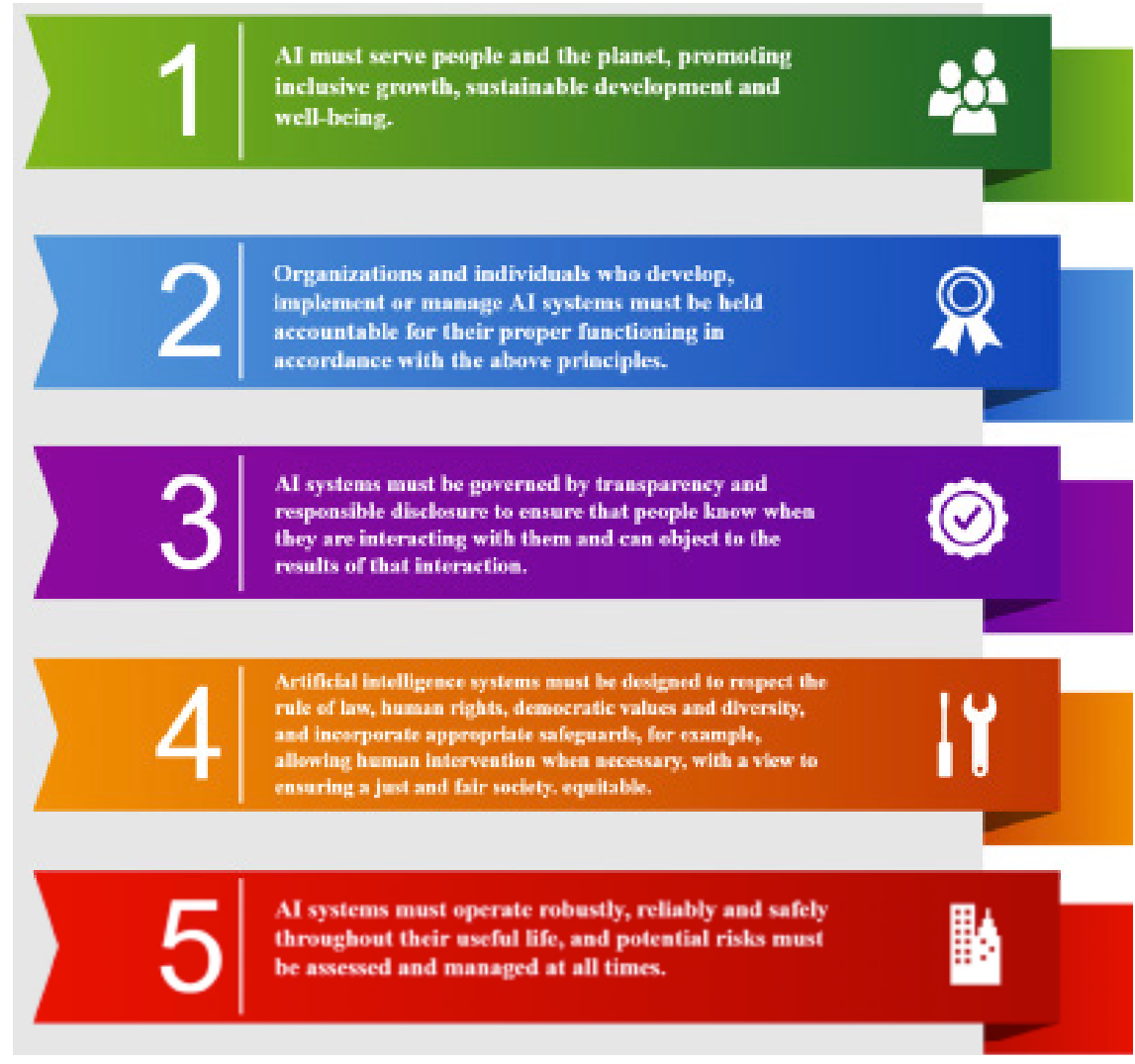

Source: OECD (2021).

The problem with the OECD is that it is only a group of consultants (Pérez de Paz, 2020). That is, this Council helps governments to design their national legislation, but it does not legislate itself. Therefore, these guidelines are not legally binding, and it is up to each member country to include them or not in their legislation. The OECD is a "parallel legislation" (Pérez de Paz, 2020, p. 66). This case is very similar to what happened - and continues to happen - with nuclear weapons agreements, in which each country, at its convenience, adopts or rejects legislative proposals presented by international consultative bodies. A significant case is the first attempt to legislate on the nuclear bomb. The Soviet Union, not convinced of the legal parameters, did not adhere to the established recommendations and manufactured the H-bomb. 


\section{(Figure 5.4)}

RECOMMENDATIONS FOR PUBLIC POLICIES AND INTERNATIONAL COOPERATION

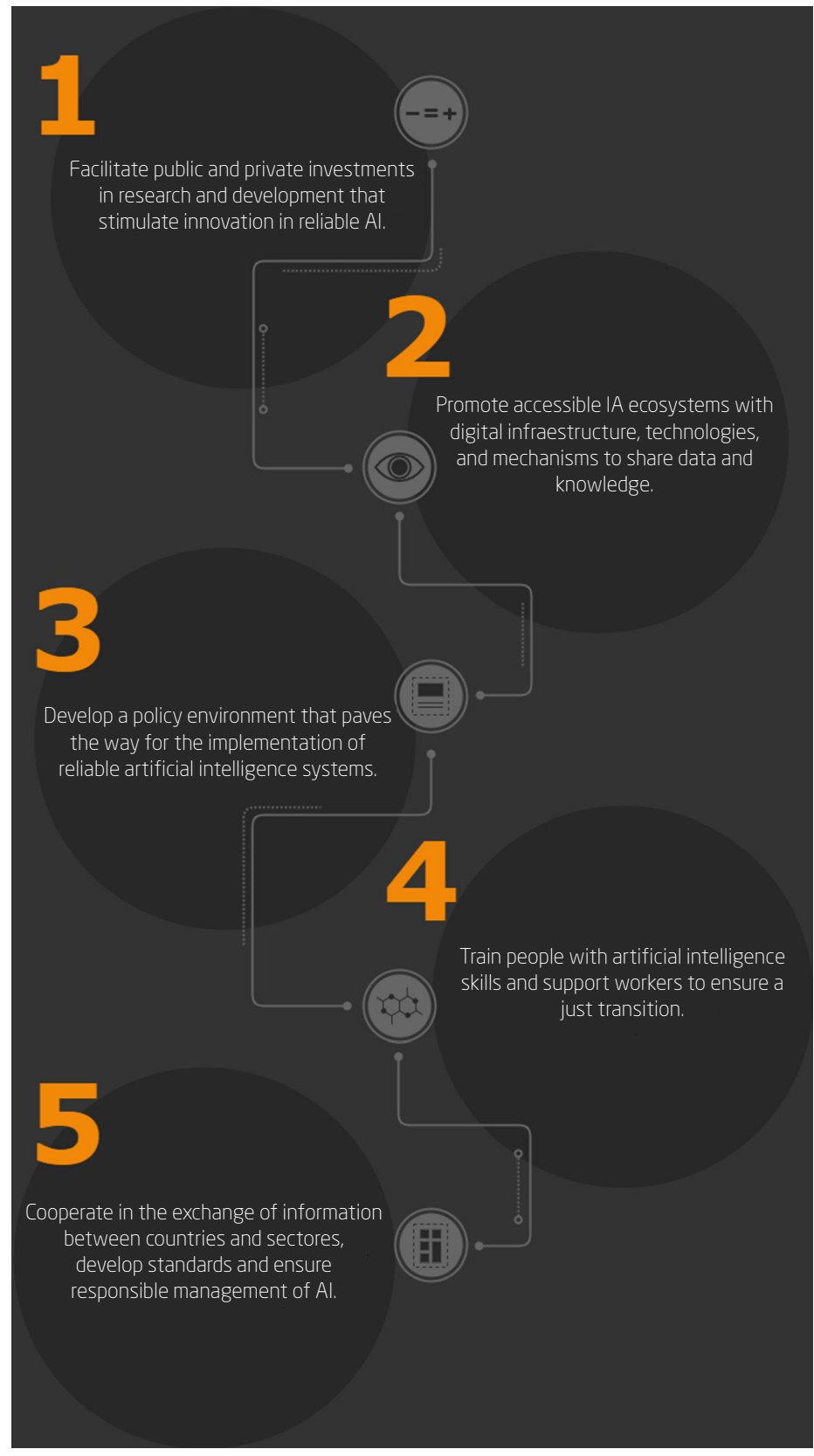

Source: OECD (2021) 
The European Parliament governs the member countries of the European Union. Among them are 5 of the top 10 AI patent producers: Germany, Denmark, Spain, Sweden, and Austria. There are currently six registered legislative processes on artificial intelligence (Figure 5.5).

\section{(Figure 5.5) \\ LEGISLATIVE PROCESSES REGISTERED IN THE EUROPEAN PARLIAMENT ON AI}

1. Intellectual property rights for the development of artificial intelligence technologies.

2. Framework of ethical aspects of $A l$, robotics and related technologies.

3. Civil liability regime for $A l$.

4. Artificial intelligence in education, culture and the audiovisual sector.

5. Artificial intelligence in criminal law and its use by the police and judicial authorities in criminal matters.

6. Civil law rules on robotics.

Fonte: Elaborated by the authors.

The current status of processes 1 to 5 is: pending committee decision. Among these processes, it is interesting to note that the framework of ethical aspects of artificial intelligence has been pending since 2012; and the civil liability regime for AI since 2014. Civil law norms in robotics are, to date, the only approved process. The votation took place in 2017 , according to the text adopted by the Parliament (Pérez de Paz, 2020). Contrary to what its title might suggest, the objective of process 6 is not to establish specific laws on the creation of robots with AI but to insist on the need for an ethical framework based on the principles of beneficence, autonomy, and justice.

The Parliament intends to establish a code for the development, design, production, use, and modification of robots. However, what is has really achieved so far is recommending that researchers and designers act respon- 
sibly and take into account respect for people's dignity, privacy, and safety (Pérez de Paz, 2020). Therefore, to date, there is no official legislation of the European Parliament on the ethical framework of artificial intelligence or on the rules for its operation. Despite this, there is a regulatory framework 2013/2682 (RSP) (Parlamento Europeo, 2013) - for collecting and using personal data in technological means that falls short by not regulating AI.

Data and information are the main inputs of today's society. However, in the absence of regulation for the media that use this information, fear may be generated about the use that can be given to it, legally or illegally. Organizations of all kinds and individuals must use technologies within a regulatory framework based on ethics and morals. The fact that there are no laws does not mean that traditional CSR does not evolve before the changes that organizations are undergoing due to the technologies of the industry 4.0. On the contrary, the absence of these regulations makes it possible to identify the need for a new form of responsibility in organizations. It is about CDR.

\subsection{Epistemological and ontological considerations for CDR}

In this section, CDR is proposed as a new application scenario for traditional CSR. However, some authors considered that their studies and approaches should be given separately. Therefore, the main discussions about the epistemological and ontological support of the CDR are presented here. Additionally, the authors' position regarding its status is proposed.

It should be noted that, to begin with, the technological frameworks on which the CDR should be used are industries 4.0 and all the technologies that cover it, especially those related to the generation, storage, and use of data. Similarly, this technological scenario leads to the emergence of new interest groups for the CDR: digital actors. All of this forms the areas of application for this new subject of Social Responsibility. The main positions on the subject are presented below.

The first position revolves around the separation between responsibility in digitization and traditional CSR. In this regard, Lobschat et al. (2019) considered this separation into three elements: 1. technological developments are presented exponentially; 2 . ethical concerns must understand the malleability of digital technologies; and 3. the need to address these problems comes from the omnipresence of digital technologies in all aspects of people and organizations.

In the case of the former element, the speed with which technology evolves must be taken into account, and the possibility of more disruptive 
technologies appearing must be anticipated. For the second one, it is necessary to identify that digital technologies can be shaped for different uses (Richter \& Riemer, 2013). Therefore, the intentions with which they were created can be modified and allow the appearance of phenomena such as fake news, information manipulation, user spying, among many others (Aparicio, 2002; Fazio, 2020; Shu, Sliva, Wang, Tang, \& Liu, 2017; Vosoughi, Roy, \& Aral, 2018). In the third one, there is evidence of an impossibility of executing daily activities in organizations without direct or indirect technological dependence.

The second position, which is the one held in this document, addresses CDR as a new subject of the traditional CSR. Digital contexts cannot be treated apart from the traditional ones as the organizations and people that make up society have adopted digital technology as part of their lives. Currently, there is no everyday aspect devoid of technological intervention. Therefore, proposing a new form of responsibility circumscribed only to the technological context leaves a void with respect to the total of activities carried out by people and organizations.

However, although technology is the channel and the instrument, social activities do not focus solely on the technological factor. Decision-making is autonomous through AI or carried out by a person based on information, affecting directly or collaterally other people and actors. This factor alone justifies the integration of the CDR as an additional component of the traditional SR and not as a proposal that replaces it or coexists with it. This is how it is proposed that CSR is a new subject or scope of application for traditional CSR (Londoño-Cardozo, 2020). Its application must be transversal and consider the technological factors, the new interested groups, and the new social, corporate, and labor figures that arise.

\subsection{Industry 4.0 seen from the CDR}

Currently, the information is tailored to individuals and organizations (Balladares, 2017). This makes it susceptible for manipulations to be in sync with the needs of users, the configuration of tastes, trends, and ways of thinking. Technology allows people to access information that they consider relevant an are in accordance with their preferences. However, AI experts have denounced a possible adulteration of the data that inhibits the information that the person acquires. With this, they manipulate their taste and preferences and create false needs (Howard, 2020; Orlowski, 2020), which corrupts their decision-making capacity and criteria and eliminates 
the possibility of having true critical thinking. The debate does not focus on quantity or quality of information but on how technology allows its attainment and final use.

Information is the main input of people and organizations for decisionmaking and is one of the components of greatest interest to the CDR. For 2015, an information production of 35 zettabytes (ZB) or 35 billion terabytes was estimated for 2020 (Camargo-Vega, Camargo-Ortega, \& JoyanesAguilar, 2015), something possible thanks to the industry. However, given the health contingency experienced during much of the year 2020, it was necessary to transform many tasks that were done in a digital way. Therefore, it is estimated that the amount of information currently generated is considerably higher than expected. This is one of the cases that the RDO must deal with.

\subsection{CDR stakeholders}

CDR, like traditional CSR, has stakeholder groups. Figure 5.3.1 shows that artificial and technological actors join the traditional stakeholders of CSR. In other words, in this context, AI, machines, and other algorithmic decision mechanisms must be considered. Another factor are the organizations, identified as: 1 . entities that fight for their survival based on the ability to motivate social actors (Pfeffer, 2000) and their role as a meeting point of interest and objectives of different groups and individual interests (Méndez Picazo, 2005), which go beyond their interests (Tello-Castrillón, 2009); 2. inalienable actors in the function of society (Tello-Castrillón, 2018a), which makes them a collective means for individual mobility by offering a structure for people's actions (North, 1992, 2006); and 3. are primarily responsible for digital actions.

Additionally, the technology necessary for the operation and support of activities with digital help is used mostly by organizations. However, the role of individuals in its use, support, and creation cannot be ignored. In this context, people both in their role as part of organizations and in an individualized context, are actors responsible for using technology, data, and the information they manage. Regarding institutional actors, mention must be made of government entities, judicial powers, law enforcement agencies, and the national and international legal and constitutional framework (Lobschat et al., 2019) that must also implement CDR policies in accordance with their action mechanisms. 


\section{(Figure 5.3.1)}

\section{CDR STAKEHOLDERS}



Source: Elaborated by the authors based on Lobschat et al. (2019, p. 7) and Thelisson, Morin, and Rochel (2020).

\subsection{CDR application cases}

In the beginning, social networks and digital platforms were used to allow organizations to communicate their CSR policies to interest groups (Alejos Góngora, 2014). However, as digital transformation permeated all aspects of society and organizations, the use of digital media went from being a channel of information communication to being a fundamental part of their activities.

In general, three broad categories are identified to which the CDR should be applied. These are: 1 . algorithms, AI, information that is transmitted and shared, and data management; 2 . the models of economic exchange resulting from digitization; and 3. the new organizational forms that emerge from it.

Applying the principles of social responsibility to digital responsibility starts from the same source code of the software used in the devices. The less amount of code, the more efficient is processing and transmission of data, and the less is the amount of energy required (Serrano Mena, 2020). In the same sense, the CDR recommends programmers being careful when coding algorithms that they learn. 
An example of the above is machine learning. This consists of the creation of algorithms that, based on their programming, could have some biases (Barbosa \& Chen, 2019; Serrano Mena, 2020). That is, the algorithm learns that a person with a broom is exclusively dedicated to cleaning tasks. This bias could be problematic when applying, for example, selecting candidates, awarding grants, assigning a scholarship, among others (Anderson \& Anderson, 2011). The main examples of this are the algorithms for learning habits and personal suggestions of the main social platforms.

Facebook, Instagram, Twitter, YouTube, Spotify, ResearchGate, among others are based on an algorithm that suggests to users data that it considers relevant to the person. The news section of social networks shows content related to your interests and interactions. Streaming platforms also contain an algorithm that, with each user's action, suggest other content that it considers related and according to your taste.

However, behind these suggestions, there may be other intentions that unconsciously permeate the user and intervene in "reality or in the universe of information they perceive" (Orlowski, 2020). That is, they skew the information that the subjects see, thereby modifying his criteria. However, it should not be ignored that these suggestions benefit the user by saving time searching for content of his preference or allowing him to see what he thinks he likes.

This dichotomy between what the users think they want or like and the portion of the information they actually perceive is widely debated today. This is considered to be the cause of political polarization, the growth of the anti-vaccine movement, and the flat-earthers, among others (Orlowski, 2020). Similarly, the debate about responsibility in digital platforms crosses the border of the information or content presented to users and extends itself to the information they consciously or unconsciously incorporate into them.

People consciously input contact information, credit card numbers, among others on different platforms for specific purposes such as purchasing products or services or for the simple creation of a personal profile. Similarly, most devices and platforms tend to capture information through cookies or trackers. Part of the debate to be solved by the CDR revolves around the location where this information is stored, the rights that must be assigned to it, or the use given to it. This is where advertising on platforms and mass advertising via mail, among other actions, fit. Groups interested in the information must agree to use it only for the purposes permitted by the user. In the same way, they must make their use clauses more flexible in the sense of returning the users the rights of their information. 
The foregoing raises the need to propose clear CDR policies in which the commitment of the service providers is real, that is, fundamental CSR. Although their business models or their socialization algorithms are the basis of their service, programmers and organizations must ensure that the information collected is used consistently. That is to say, that the privacy and the rights of the users are respected, that they do not disclose it to third parties and, mainly, that the information or content shown does not contain prejudice from the exposed bias.

\section{CONCLUSIONS}

This article's proposal is a necessary novelty for the current context and, therefore, it is pertinent to continue with the deepening of these issues. However, some aspects that can be highlighted were identified. In the first place, the challenge of technology for society and organizations; and, secondly, the consequences that this development entails for ethics and administration.

Technologies immersed in industry 4.0 present new challenges for all social and organizational contexts. Implementing, without any type of social regulation, technologies such as $\mathrm{AI}$ in organizations is unwise, since it is a danger that transcends the quantitative conception of risk by threatening human values. This social risk must be resolved and, for this, its very concept sheds light on where a solution could be sought. A way must be sought to universalize an ethical view of technology since it involves a society and not a single individual. This is where CDR comes into play as a means of globalizing ethics in the form of laws applicable to all members of humanity. Therefore, efforts must be made to develop public policies that allow coexistence between technological developments and people in the form of fundamental social responsibility.

The consequences of technology in organizations and the unpredictability of technology make it difficult to intuit what kind of artifacts will be implemented in the future. Therefore, this becomes one of the limits of this proposal. This work was limited to information transmission technologies. In the case of the existence of agency or completely autonomous technologies, it would be necessary to expand the scope of the CDR and possibly the very concept of organization, topics that are proposed as an object of study for future works. 


\section{A RESPONSABILIDADE DIGITAL ORGANIZACIONAL: FUNDAMENTOS E CONSIDERAÇÕES PARA SEU DESENVOLVIMENTO}

\section{) RESUMO}

Objetivo: Propor a responsabilidade digital organizacional como uma nova área de interesse da responsabilidade social nos contextos das tecnologias que fazem parte das indústrias 4.0.

Originalidade/valor: Não existe suficiente base teórica e legal que permita às organizações de diferentes tipos enfrentar as implicações da adoção das novas tecnologias. Por conseguinte, apresentam-se fundamentos e considerações essenciais para o desenvolvimento da responsabilidade digital organizacional.

Design/metodologia/abordagem: Este artigo apresenta uma pesquisa hermenêutica baseada numa revisão sistêmica de literatura realizada na estrutura de duas pesquisas. A primeira abordou a discussão sobre a pertinência da criação de uma nova matéria para a responsabilidade social tradicional em contextos digitais, e a segunda demonstrou a necessidade epistemológica da responsabilidade social nas novas tecnologias. Resultados: Em primeiro lugar, o fato de as novas tecnologias representarem supostamente um risco social faz que elas sejam assunto de estudo da responsabilidade social. Em segundo lugar, a ausência de regulamentação vigente sobre a indústria 4.0 e a imprevisibilidade do avanço das tecnologias não são limites para a criação de um cenário de responsabilidade digital organizacional. O desenvolvimento da responsabilidade social nos contextos digitais é possível e necessário. No entanto, é preciso estar atento às variáveis de risco social que possam surgir com cada nova tecnologia. Por conseguinte, é necessária uma revisão constante das bases e dos fundamentos da responsabilidade digital organizacional.

\section{PALAVRAS-CHAVE}

Risco social. Responsabilidade social organizacional. Indústrias 4.0. Transformação digital. Inteligência artificial. 


\section{REFERENCES}

Al Faruqi, U. (2019). Future service in industry 5.0. Jurnal Sistem Cerdas, 2(1), 67-79. doi:10.37396/jsc.v2i1.21

Alejos Góngora, C. L. (2014). Responsabilidad social corporativa en la era digital: De la informacion a la comunicación [Cuadernos de la Cátedra "la caixa" Cuaderno n. 25]. IESE Business School. Universidad de Navarra. Retrieved from https://media.iese.edu/research/pdfs/ST-0367.pdf

Anderson, S. L., \& Anderson, M. (2011). A prima facie duty approach to machine ethics: Machine learning of features of ethical dilemmas, prima facie duties, and decision principles through a dialogue with ethicists. In M. Anderson \& S. L. Anderson, Machine ethics (pp. 476-494). Cambridge: Cambridge University Press.

Aparicio, R. (2002). La magnitud de la manipulación del voto en las elecciones federales del año 2000. Perfiles Latinoamericanos, 20, 79-99.

Asimov, I. (2017). Yo, robot (9a reimp.). (M. Bosch Barret, Trad.). Barcelona: Edhasa.

Aßländer, M. S. (2011). Corporate social responsibility as subsidiary co-responsibility: A macroeconomic perspective. Journal of Business Ethics, 99(1), 115-128. doi:0.1007/s10551-011-0744-x

Balladares, J. (2017). Una ética digital para las nuevas generaciones digitales. Revista PUCE, 104, 543-563. doi:10.26807/revpuce.v0i0.81

Barbosa, N. M., \& Chen, M. (2019). Rehumanized crowdsourcing: A labeling framework addressing bias and ethics in machine learning. Proceedings of the 2019 CHI Conference on Human Factors in Computing Systems. doi:10.11 45/3290605.3300773

Beck, U. (2002). La sociedad del riesgo global (J. Alborés Rey, Trad.). Siglo Veintiuno.

Bernal Torres, C. A. (2010). Metodología de la investigación: Administración, economía, humanidades y ciencias sociales (3a ed.). (O. Fernández Palma, Org.). Prentice Hall.

Camargo-Vega, J. J., Camargo-Ortega, J. F., \& Joyanes-Aguilar, L. (2015). Conociendo big data. Facultad de Ingeniería, 24(38), 63-77.

Chicaíza-Becerra, L. A., Riaño Casallas, M. I., Rojas-Berrio, S. P., \& Garzón Santos, C. (2017). Revisión sistemática de literatura en administración. Facultad de Ciencias Económicas, Centro de Investigaciones para el Desarrollo CID. Retrieved from http://www.fce.unal.edu.co/centro-editorial/docu- 
mentos/escuela-de-administracion-y-contaduria-publica/1600-29- revision-sistematica-de-la-literatura-en-administracion.html

Cognilytica (2020). Worldwide AI laws and regulations 2020. Retrieved from https://www.cognilytica.com/2020/02/14/worldwide-ai-laws-andregulations-2020/

Elkington, J. (1998). Accounting for the triple bottom line. Measuring Business Excellence, 2(3), 18-22. doi:10.1108/eb025539

Elkington, J. (2004). Enter the triple bottom line. In A. Henriques \& J. Richardson, The triple bottom line: Does it all add up (pp. 1-16). Taylor \& Francis.

Enderle, G. (2010). Clarifying the terms of business ethics and CSR. Business Ethics Quarterly, 20(4), 730-732.

Fazio, L. (2020). Pausing to consider why a headline is true or false can help reduce the sharing of false news. Harvard Kennedy School Misinformation Review, 1(2). doi:10.37016/mr-2020-009

Fréminville, M. de (2020). Corporate governance and digital responsibility. In M. de Fréminville, Cybersecurity and decision makers: Data security and digital trust (pp.39-68).Hoboken:JohnWiley\&Sons. doi:10.1002/9781119720362. ch2

Friedman, M. (1970). La responsabilidad social de la empresa es incrementar sus beneficios. The New York Times Magazine, 1, 122-126.

García Molina, M., \& Chicaíza Becerra, L. (2011). Guía de fuentes para la investigación en Ciencias Económicas. (Documento FCE No. EE-22). Facultad de Ciencias Económicas, Centro de Investigaciones para el Desarrollo - CID. doi:10.2139/ssrn. 1766062

Giddens, A. (1998). Risk society: The context of British politics. In J. Franklin, The politics of risk society (p. 23-34). Cambridge: Polity Press.

Hernández Sampieri, R., Fernández Collado, C., \& Baptista Lucio, M. del P. (2014). Metodología de la investigación (6a ed.). Cidade do México: McGrawHill.

Hernández Sampieri, R., \& Mendoza Torres, C. P. (2018). Metodología de la investigación: Las rutas cuantitativa, cualitativa y mixta. Cidade do México: McGraw-Hill.

Howard, P. (2020). Lie machines: How to save democracy from troll armies, deceitful robots, junk news operations, and political operatives. New Haven, CT: Yale University Press. 
International Organization for Standartization (2010). ISO 26000:2010: Guía de responsabilidad social. Retrieved from https://www.iso.org/obp/ ui\#iso:std:iso:26000:ed-1:v1:es

Jenkins, R. (2009). What is corporate social responsibility? In J. Peil \& I. van Staveren, Handbook of economics and ethics (pp. 69-76). Edward Elgar.

Kasperson, R. E., Renn, O., Slovic, P., Brown, H. S., Emel, J., Goble, R., Kasperson, J. X., \& Ratick, S. (1988). The social amplification of risk: A conceptual framework. Risk Analysis, 8(2), 177-187. doi:10.1111/j. 1539-6924.1988.tb01168.x

Kermisch, C. (2011). Le concept de risque: De l'épistémologie à l'éthique. Paris: Tec \& Doc Lavoisier.

Lobschat, L., Mueller, B., Eggers, F., Brandimarte, L., Diefenbach, S., Kroschke, M., \& Wirtz, J. (2019). Corporate digital responsibility. Journal of Business Research. doi:10.1016/j.jbusres.2019.10.006

Londoño-Cardozo, J. (2020). Propuesta de caracterización de la responsabilidad digital organizacional de la economía colaborativa (Trabajo de grado de pregrado en Administración, Universidad Nacional de Colombia). Retrieved from https://www.researchgate.net/publication/347986045_Propuesta_de_caracterizacion_de_la_responsabilidad_digital_organizacional_de_la_economia_colaborativa

Lozano Correa, L. J. (2017). La confianza y su incidencia en los grupos de interés. In N. Gorrochategui, V. Martins de Oliveira, A. P. Hernández Bernal, \& L. F. Moreno Garzón, Responsabilidad social de las organizaciones (RSO): Aportes teórico-prácticos para lograr los Objetivos de Desarrollo Sostenible en América Latina (pp. 481-492). Bogotá: Universidad Santo Tomás.

Maisiri, W., Darwish, H., \& Dyk, L. van (2019). An investigation of industry 4.0 skills requirements. South African Journal of Industrial Engineering, 30(3), 90-105. doi:10.7166/30-3-2230

Melnyk, L. H., Kubatko, O. V., Dehtyarova, I. B., Dehtiarova, I. B., Matsenko, O. M., \& Rozhko, O. D. (2019). The effect of industrial revolutions on the transformation of social and economic systems. Problems and Perspectives in Management, 17(4), 381-391. doi:10.215 11/ppm.17(4).2019.31

Méndez Picazo, M. T. (2005). Ética y responsabilidad social corporativa. Información Comercial Española, ICE: Revista de Economía, 823, 141-151.

Molina García, M. (2011). El teléfono móvil: De los inicios a la actualidad. In R. S. Contreras \& I. García Medina, M-Todos, tendencias y oportunidades de 
la movilidad digital (pp. 97-107). Vic: Universitat de Vic. Retrieved from http://dspace.uvic.cat/xmlui/handle/10854/1873

Navarro Güere, H. (2011). El triunfo de las tabletas. In R. S. Contreras \& I. García Medina, M-Todos, tendencias y oportunidades de la movilidad digital (pp. 108-115). Vic: Universitat de Vic. http://dspace.uvic.cat/xmlui/handle/10854/1873

North, D. C. (1992). Instituciones, ideología y desempeño económico. Washington, D. C.: Cato Institute.

North, D. C. (2006). Instituciones, cambio institucional y desempeño económico (3a reimp.) (A. Bárcena, Trad.). Fondo de Cultura Económica.

Olivero Arias, E., Morales Vergara, R., \& Alvarado Márquez, M. (2017). Identificación de los principios de los stakeholders en una asociación de agricultores arroceros, componente del desarrollo rural. In N. Gorrochategui, V. Martins de Oliveira, A. P. Hernández Bernal, \& L. F. Moreno Garzón, Responsabilidad social de las organizaciones (RSO): Aportes teórico-prácticos para lograr los Objetivos de Desarrollo Sostenible en América Latina (pp. 147-172). Bogotá: Universidad Santo Tomás.

Organisation for Economic Co-operation and Development (2021). Recommendation of the Council on OECD Legal Instruments Artificial Intelligence. Retrieved from https://legalinstruments.oecd.org/en/instruments/ OECD-LEGAL-0449

Orlowski, J. (Dir.). (2020). El dilema de las redes sociales (Filme). Retrieved from Netflix. https://genunpal.page.link/MtPs

Özdemir, V., \& Hekim, N. (2018). Birth of industry 5.0: making sense of Big Data with artificial intelligence, "the internet of things" and next-generation technology policy. OMICS: A Journal of Integrative Biology, 22 (1), 65-76. doi:10.1089/omi.2017.0194

Parlamento Europeo (2013). 2013/2682(RSP). Retrieved from https://oeil. secure.europarl.europa.eu/oeil/popups/printficheglobal.pdf?id=628555 $\& l=\mathrm{en}$

Pérez de Paz, M. (2016). Homo compensator: Le parcours philosophique d'un concept métaphysique (Universidad de Poitiers, França). doi:10.13140/RG. 2.2.28294.91209

Pérez de Paz, M. (2020). Transhumanisme et bioconservateurs le problème du développement de la Superintelligence (Université Paris 8, França). doi:10.13 140/RG.2.2.23652.09603 
Perrone, C. M., Engelman, S., \& Reppold, A. R., Filho (2014). Desafíos contemporáneos de la ética y de la moral en las organizaciones. Invenio: Revista de Investigación Académica, 17(31-32), 33-47.

Pfeffer, J. (2000). Nuevos rumbos en la teoría de la organización: Problemas y posibilidades (M. D. P. Carril Villarreal, Trad.). Cidade do Médico: Universidad Iberoamericana.

Renn, O., \& Rohrmann, B. (Orgs.) (2000). Cross-cultural risk perception: A survey of empirical studies. Boston: Springer.

Richter, A., \& Riemer, K. (2013). Malleable end-user software. Business \& Information Systems Engineering, 5(3), 195-197. doi:10.1007/s12599-0130260-x

Rincón Orozco, C. D. (2020). Qué es la ética organizacional. In C. Tello-Castrillón, E. F. Pineda-Henao, \& J. Londoño-Cardozo, La construcción organizacional de la responsabilidad social: Fundamentos teóricos y casos de estudio (pp. 57-73). Bogotá: Universidad Nacional de Colombia.

Sanz Pereda, J. (2018). Robots industriales colaborativos: Una nueva forma de trabajo. Seguridad y Salud en el Trabajo, 95, 6-10.

Serrano Mena, A. (2020). Ética, software y sostenibilidad. OpenMind. Retrieved from https://www.bbvaopenmind.com/tecnologia/innovacion/ software-sostenibilidad-etica/

Shu, K., Sliva, A., Wang, S., Tang, J., \& Liu, H. (2017). Fake news detection on social media: A data mining perspective. ACM SIGKDD Explorations Newsletter, 19(1), 22-36. doi:10.1145/3137597.3137600

Skobelev, P., \& Borovik, S. Y. (2017). On the way from industry 4.0 to industry 5.0: From digital manufacturing to digital society. Industry 4.0, 2(6), 307-311.

Sosa Cardona, R. E., Tello-Castrillón, C., \& Pineda Henao, E. F. (2020). Derecho constitucional, responsabilidad social organizacional y gobernanza: El caso de empresas municipales de Cali. Justicia, 25(37), 227-244. doi:10. 17081 just.25.37.4153

Tello-Castrillón, C. (2009). Abordaje de conceptos sobre la organización. Bogotá: Universidad Nacional de Colombia.

Tello-Castrillón, C. (2014). Neoinstitucionalismo, responsabilidad social organizacional y gobernanza. Cuestiones Políticas, 30(52), 116-130.

Tello-Castrillón, C. (2018a). El concepto de organización, tan cerca y tan lejos. In C. Tello-Castrillón \& E. F. Pineda-Henao, Conjeturas organizacio- 
nales: Fundamentos para el estudio de la organización (pp. 79-102). Bogotá: Universidad Nacional de Colombia.

Tello-Castrillón, C. (2018b). Relación entre el gobierno corporativo y la responsabilidad social organizacional: Estudio de caso en una empresa multilatina colombiana, Carvajal S. A. (Tesis doctoral, Universidad Nacional de Colombia, Manizales). Retrieved from http://bdigital.unal.edu.co/65743/1/16774542.2018.pdf

Tello-Castrillón, C. (2021a). Corporate governance and organizational social responsibility: Discussion about the Multilatins case. Cuadernos de Administración, 37(71), e2310975.

Tello-Castrillón, C. (2021b). Discusión sobre la relación entre aspectos políticos del gobierno corporativo y la responsabilidad social organizacional en las multilatinas. Universidad del Valle.

Tello-Castrillón, C., \& Londoño-Cardozo, J. (2020). Responsabilidad social organizacional, definiciones y aplicación. In C. Tello-Castrillón, E. F. Pineda-Henao, \& J. Londoño-Cardozo, La construcción organizacional de la responsabilidad social: Fundamentos teóricos y casos de estudio (pp. 75-113). Bogotá: Universidad Nacional de Colombia.

Tello-Castrillón, C., \& Rodríguez Córdoba, M. del P. (2014). Categorías conceptuales para el estudio de la responsabilidad social organizacional. Hallazgos, 11 (22), 119-135. doi:10.15332/s1794-3841.2014.0022.07

Tello-Castrillón, C., \& Rodríguez Córdoba, M. del P. (2016). Fundamentos ético disciplinares de la responsabilidad social organizacional. Revista Venezolana de Gerencia, 21 (75), 491-508.

Tello-Castrillón, C., Rodríguez Córdoba, M. del P., \& Varela Barrios, E. (2013). El gobierno corporativo de las multilatinas y su responsabilidad social organizacional. Congreso Internacional de Contaduría, Administración e Informática, 18, México. Retrieved from http://premio.investiga.fca.unam.mx/docs/ XVIII/XVIII-3TDLEL\%20GOBIERNO\%20CORPORATIVO\%20DE\%20 LAS.pdf

The Global Compact (2000). Los diez principios del Pacto Global. Retrieved from http://www.pactoglobal.uy/index.php/pacto-global/10-principios

Thelisson, E., Morin, J.-H., \& Rochel, J. (2020). AI governance: Digital responsibility as a building block. Delphi - Interdisciplinary Review of Emerging Technologies, 2(4), 167-178. doi:10.21552/delphi/2019/4/6

Ungericht, B., \& Hirt, C. (2010). CSR as a political arena: The struggle for a European framework. Business and Politics, 12(4), 1-22. 
United Nations Interregional Crime and Justice Research Institute (2020). Artificial intelligence and robotics. Retrieved from http://www.unicri.it/ topics/ai_robotics

Vaidya, S., Ambad, P., \& Bhosle, S. (2018). Industry 4.0 - A glimpse. Procedia Manufacturing, 20, 233-238. doi:10.1016/j.promfg.2018.02.034

Val Román, J. L. del (2016a). Industria 4.0: La transformación digital de la industria. Conferencia de Directores y Decanos de Ingeniería Informática. Retrieved from http://coddii.org/wp-content/uploads/2016/10/Informe-CODDIIIndustria-4.0.pdf

Val Román, J. L. del (2016b). Industria 4.0: La transformación digital de la industria. Deusto Ingeniería. Retrieved from https://revistaingenieria.deusto.es/tag/industria-4-0/

Volpentesta, J. R. (2015). Procedimientos administrativos en la gestión de los stakeholders. In N. Gorrochategui, V. Martins de Oliveira, J. Domínguez Granda, \& H. Chero Valdivieso, Responsabilidad social de las organizaciones: Avances y propuestas en América Latina (pp. 59-90). Chimbote: Universidad Católica Los Ángeles de Chimbote.

Volpentesta, J. R. (2017). Método de integración de stakeholders a procesos de toma de decisiones de las empresas. In N. Gorrochategui, V. Martins de Oliveira, A. P. Hernández Bernal, \& L. F. Moreno Garzón, Responsabilidad social de las organizaciones (RSO): Aportes teórico-prácticos para lograr los Objetivos de Desarrollo Sostenible en América Latina (pp. 89-108). Universidad Santo Tomás.

Vosoughi, S., Roy, D., \& Aral, S. (2018). The spread of true and false news online. Science, 359(6380), 1146-1151. doi:10.1126/science.aap9559

Weyrich, M., Schmidt, J., \& Ebert, C. (2014). Machine-to-machine communication. IEEE Software, 31 (4), 19-23. doi:10.1109/MS.2014.87

Xu, M., David, J. M., \& Kim, S. H. (2018). The Fourth Industrial Revolution: Opportunities and challenges. International Journal of Financial Research, 9(2), 90-95. doi:10.5430/ijfr.v9n2p90

\section{AUTHOR NOTES}

José Londoño-Cardozo, master from the Faculty of Engineering and Administration, Universidad Nacional de Colombia (Unal) - Sede Palmira; María Pérez de Paz, master from the Faculdade de Artes \& Humanidades e Ciências Sociais, Universidade Paris 8. 
José Londoño-Cardozo is now a researcher at the Grupo de Estudios Neoinstitucionales (GEN), Department of Social Sciences of Unal - Sede Palmira; María Pérez de Paz is now a researcher in Applied Philosophy at GEN, Department of Social Sciences of Unal - Sede Palmira.

Correspondence concerning this article should be addressed to José Londoño-Cardozo, Rua 69 No 4an-32, Calima, Cali, Valle del Cauca, Colômbia, Código Postal 760002.

E-mail: jodlondonoca@unal.edu.co

\section{EDITORIAL BOARD}

Editor-in-chief

Gilberto Perez

Associate editor

Rodrigo Baroni de Carvalho

Technical support

Vitória Batista Santos Silva

\section{EDITORIAL PRODUCTION}

Publishing coordination

Jéssica Dametta

Language editor

Daniel de Almeida Leão

Layout designer

Emap

Graphic designer

Libro 